\title{
PENGARUH DIVERSIFIKASI TERHADAP RISIKO PORTOFOLIO SAHAM (KASUS 5 SAHAM SEKTOR PERTAMBANGAN DI BURSA EFEK INDONESIA)
}

\author{
JUNAEDI \\ MOH. NOVAL \\ CICI RIANTY K. BIDIN \\ Program Studi S1 Manajemen, Fakultas Ekonomi, Universitas Tadulako \\ Email: junaedyfold27@gmail.com
}

\begin{abstract}
The purpose of this study is to explain the effect of diversification on the risk of stock portfolio of mining sector in Indonesia Stock Exchange. Sampling techniques using is purposive sampling with 5 sample of stocks from the mining sector in the BEI. Analyzer uses variance-covariance. The results of this study are: 1) The risk on portfolio 1 share (ADRO) reached 7.2\%. When MEDC shares were added, portfolio risk decreased significantly to $0.72 \%$. BUMI shares were included, portfolio risk rose to $0.75 \%$. When ANTM and PTBA stocks added portfolio risk increased respectively to $0.96 \%$ and $5.7 \%$. 2) Diversification affects portfolio risk when the portfolio only forms up to 3 stocks are ADRO, MEDC and BUMI, so the initial hypothesis is accepted. However, when ANTM and PTBA stocks are added to the portfolio, the risk is increased so that the initial hypothesis is rejected for the 5 stock portfolio. Proportion of funds in portfolio 3 shares, namely; 81.3\% (ADRO), 10.7\% (MEDC) and 8\% (BUMI) will generate portfolio risk of $0.75 \%$ and expected return of $2.5 \%$.
\end{abstract}

Keyword: Investment, Diversification, Return dan Risk, Portfolio, Variance-Covariance

\section{Abstrak}

Tujuan penelitian ini adalah untuk menjelaskan diversifikasi dan risiko portofolio beserta pengaruh diversifikasi terhadap risiko portofolio serta menentukan jumlah saham yang membentuk portofolio optimal. Teknik penarikan sampel menggunakan purposive sampling dengan sampel sebanyak 5 saham dari sektor pertambangan di BEI. Alat analisis menggunakan variance-covariance. Adapun hasil penelitian ini adalah: 1) Risiko pada portofolio 1 saham (ADRO) mencapai 7.2\%. Ketika saham MEDC ditambahkan, risiko portofolio mengalami penurunan yang signifikan menjadi $0.72 \%$. Saham BUMI kemudian dimasukkan, risiko portofolio naik menjadi 0.75\%. Ketika saham ANTM dan PTBA ditambahkan risiko portofolio naik masing-masing menjadi 0.96\% dan 5.7\%. 2) Diversifikasi dengan menambahkan 5 saham sektor pertambangan, awalnya menurunkan risiko portofolio hingga 3 saham. Ketika saham ANTM dan PTBA ditambahkan risiko portofolio mulai meningkat. 3) Proses diversifikasi yang dilakukan, tidak memiliki pengaruh terhadap risiko portofolio saham. 4) Portofolio optimal terdapat pada portofolio 3 saham yaitu ADRO, MEDC dan BUMI dengan proporsi dana masing-masing 81.3\%, 10,7\% dan 8\%, dengan risiko portofolio sebesar $0.75 \%$ dan return ekspektasi sebesar $2.5 \%$.

Kata kunci: Investasi, Diversifikasi, Return dan Risiko, Portofolio, Varian-Covariance

\section{PENDAHULUAN}

Investasi sudah menjadi kegiatan yang tidak dapat dipisahkan dari kehidupan modern. Para pemilik modal lebih memprioritaskan modalnya ke dalam bentuk investasi, baik berupa aset riil (seperti tanah, bangunan, dan mesin) maupun aset finansial berupa surat-surat berharga (seperti saham dan obligasi). Tujuan investasi ini dilakukan adalah untuk memperoleh keuntungan yang lebih di masa yang akan datang. Investasi akan lebih menguntungkan jika dibanding hanya mengonsumsinya saat ini.

Para investor cenderung menanamkan modalnya pada pasar modal dalam bentuk saham. Berinvestasi pada surat berharga ini, diyakini akan mendatangkan keuntungan yang sesuai dengan 
modal yang dinvestasikan. Namun, masalah utama yang selalu dihadapi para investor ketika berinvestasi pada surat berharga seperti saham adalah risiko. Risiko ini timbul akibat adanya hubungan positif antara keuntungan yang diharapkan dengan risiko yang akan dihadapi (high risk high return, low risk low return). Istilah ini juga sejalan dengan teori yang dikemukakan oleh Markowitz (1952) bahwa jika seorang investor mengharapkan return (keuntungan) yang tinggi, tingkat risikonya pun akan tinggi. Akibatnya, imbal hasil yang diharapkan dalam investasi itu masih berupa harapan atau belum pasti terjadi.

Berdasarkan kondisi itu pada tahun 1952, Markowitz melakukan sebuah penelitian yang berjudul "portfolio selection". Penelitian ini, menjelaskan bahwa dengan melakukan diversifikasi melalui portofolio, yaitu menggabungkan berbagai instrumen keuangan yang berbeda dan membentuknya ke dalam sebuah portofolio akan dapat mengeleminasi risiko total yang ada. Meskipun diversifikasi tidak dapat menghilangkan risiko secara keseluruhan, tetapi diversifikasi dapat meminimalkan risiko hingga hanya menyisakan systematic risk. Keinginan investor untuk mendapatkan return yang tinggi dengan risiko yang rendah atau return tertentu dengan risiko yang mampu ditanggungnya dapat tercapai.

\section{KAJIAN LITERATURE DAN PENGEMBANGAN HIPOTESIS}

\section{Investasi}

Jones (2004:3) mendefinisikan investasi sebagai "The commitment of funds to one or more assets that will be held over some future time period. Bodie et al, (2014:1) mendefinisikan investasi sebagai komitmen saat ini atas uang atau sumber daya lain dengan harapan untuk mendapatkan keuntungan dimasa depan. Fahmi (2015:3) membagi investasi ke dalam dua bentuk yaitu investasi nyata (real investment) dan investasi keuangan (financial investment). Investasi nyata (real investment) secara umum melibatkan aset berwujud seperti; tanah, mesin, dan pabrik. Sedangkan investasi keuangan (financial investment) melibatkan kontrak tertulis, seperti saham dan obligasi.

\section{Portofolio}

Samsul (2006:301) portofolio merupakan investasi dalam berbagai instrumen keuangan atau disebut juga diversifikasi. Tyas Auruma dan Sudana (2013:27) menambahkan bahwa cara melakukan diversifikasi adalah menyusun isi portofolio dengan instrumen keuangan seperti saham, obligasi, dan lain-lain, yang hasilnya disebut dengan portofolio. Portofolio dibagi menjadi portofolio efisien dan portofolio optimal. Awat dan Muljadi (1996:237), mengatakan bahwa portofolio dikatakan efisien apabila tidak ada lagi portofolio lain yang memiliki harapan keuntungan tertinggi dengan risiko terendah. Sedangkan Portofolio optimal adalah kumpulan dari portofolio efisien yang mampu memberikan return yang sesuai dengan keinginan investor terhadap return dan risiko yang bersedia ditanggungnya.

\section{Diversifikasi}

Jones (2004:179) mendefinisikan "diversification is the key to the management of portfolio risk because it allows investors significantly to lower portfolio risk without adversely affecting return. Titman, et al (2011:229) mengatakan bahwa "The effect of reducing risks by including a large number of investment in a portfolio is called diversification."

\section{Return}

Harjito dan Martono (2014:414) Return merupakan tingkat pengembalian hasil yang diperoleh oleh para investor yang menanamkan atau menginvestasikan sejumlah dananya pada saham dan periode tertentu. Adapun rumus return saham menurut Jogiyanto (2014:20) yaitu:

Sedangkan, return portofolio ekspektasi menurut Jogiyanto (2014:148) yaitu: 


\section{Risiko}

Jones (2004:173) "risk is the change that the actual return from an investment will differ from its expected return." Sudana (2011:34) mendefinisikan risiko sebagai variabilitas hasil investasi yang sesungguhnya terhadap hasil investasi yang diharapkan. Adapun rumus risiko atau standar deviasi menurut Jogiyanto (2014:148) adalah sebagai berikut:

$$
\Sigma \quad \Sigma
$$

\section{Variance-Covariance}

Jogiyanto (2014:33) varian (variance) adalah kuadrat dari standar deviasi. Varian dan standar deviasi inilah yang biasanya diartikan sebagai risiko pada investasi saham. Jogiyanto (2014:34) mendefinisikan kovarian sebagai pengukur yang menunjukkan arah pergerakan dua buah variabel. Adapun rumus kovarian adalah sebagai berikut:

$$
\Sigma
$$

Menurut Muslich (1997:22), kovarian dapat bernilai positif, negatif atau 0. Kovarian yang bernilai positif mencerminkan bahwa hasil dari investasi yang satu lebih besar daripada hasil yang diharapkan, demikian pula dengan hubungan return investasi yang lainnya, sebaliknya kovarian yang bernilai negatif menunjukkan bahwa jika hasil dari investasi yang satu lebih besar daripada hasil yang diharapkan. Maka hasil investasi yang lain akan lebih kecil dari hasil yang diharapkannya, demikian sebaliknya kovarian yang bernilai negatif cenderung akan mengurangi risiko kedua investasi, sedangkan kovarian yang bernilai 0 berarti bahwa hasil antara kedua investasi berfluktuasi secara independen antara yang satu dengan yang lainnya. Kovarian yang bernilai 0 akan mengurangi risiko dari kedua investasi.

\section{Pasar Efisiensi}

Van Horne (2002:49) Sebuah pasar dikatakan efisien jika seluruh informasi tersedia menentukan harga. Fama (1970) mendefinisikan pasar efisien sebagai suatu "fair-game" dimana harga selalu menggambarkan secara penuh seluruh informasi yang tersedia. Muslich (1997:11) mendefinisikan bahwa jika harga pasar cepat dengan adanya informasi baru maka pasar adalah efisien.

\section{Kerangka Pemikiran}

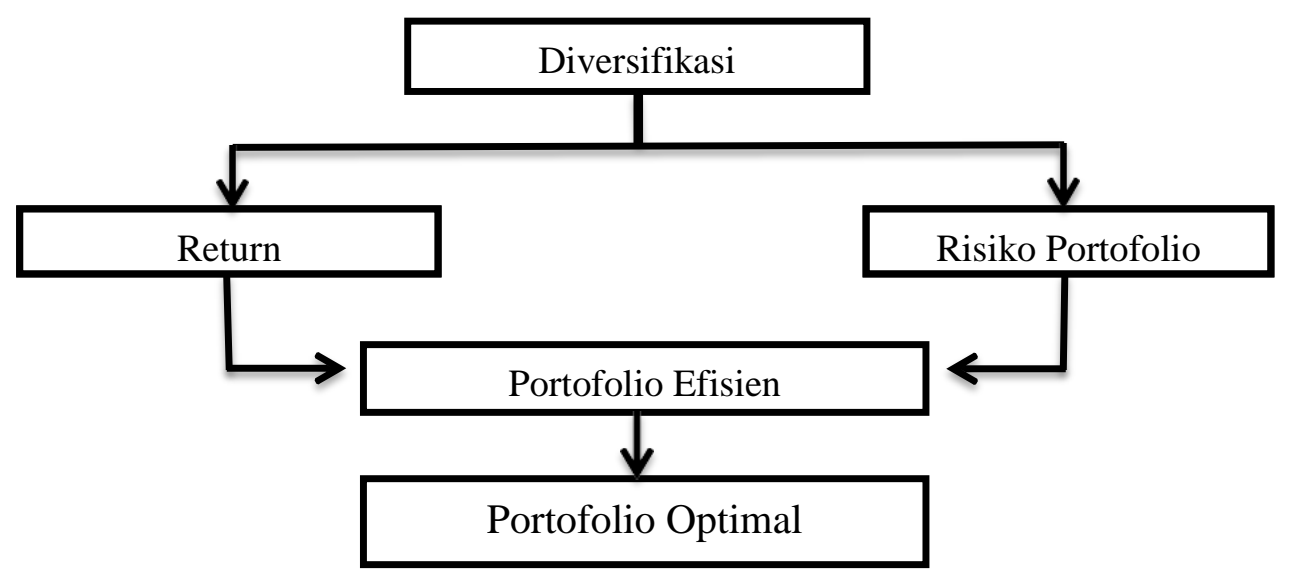

Gambar 1 Kerangka Pemikiran 


\section{Hipotesis}

Berdasarkan latar belakang dan kerangka pemikiran diatas, dugaan sementara yang diajukan oleh peneliti dalam penelitian ini atas masalah yang telah dirumuskan adalah sebagai berikut:

$\mathrm{H}_{1}$ : Diduga bahwa Diversifikasi mempengaruhi Risiko Portofolio Saham.

\section{METODE PENELITIAN}

Jenis penelitian ini adalah verifikatif. Menurut Sugiyono (2014:21), pendekatan verifikatif pada dasarnya untuk menguji teori dengan pengujian hipotesis. Pengujian hipotesis dilakukan dengan menggunakan perhitungan statistik yang digunakan untuk menguji variabel $\mathrm{X}$ terhadap variabel $\mathrm{Y}$ yang diteliti. Verifikatif berarti menguji teori dengan pengujian suatu hipotesis apakah diterima atau ditolak. Adapun variabel dalam penelitian ini meliputi Return dan Risiko. Variabel dan definisi operasional variabel dalam penelitian ini telah disajikan pada tabel 1 berikut ini:

Tabel 1 Definisi Operasional Variabel

\begin{tabular}{|c|c|c|c|c|}
\hline No. & Variabel & Konsep & Indikator & Ukuran \\
\hline 1 & Return & $\begin{array}{l}\text { Return atau pengembalian yang } \\
\text { diharapkan Menurut Harjito dan } \\
\text { Martono (2014:414) merupakan } \\
\text { tingkat pengembalian hasil yang } \\
\text { diperoleh para investor yang } \\
\text { menanamkan atau menginvestasikan } \\
\text { sejumlah dananya pada saham dan } \\
\text { periode tertentu. }\end{array}$ & $\begin{array}{l}\text { Harga saham } \\
\text { perusahaan } \\
\text { industri } \\
\text { manufaktur di } \\
\text { BEI. }\end{array}$ & \\
\hline 2 & Risiko & $\begin{array}{l}\text { Harjito dan Martono (2014:175) } \\
\text { mendefinisikan risiko sebagai } \\
\text { penyimpangan hasil (return) yang } \\
\text { diperoleh dari rencana hasil (return) } \\
\text { yang diharapkan. }\end{array}$ & $\begin{array}{l}\text { Risiko saham } \\
\text { perusahaan } \\
\text { industri } \\
\text { manufaktur di } \\
\text { BEI }\end{array}$ & $\sum \Sigma$ \\
\hline
\end{tabular}

\section{Sumber: Data diolah}

Jenis data yang digunakan dalam penelitian ini adalah data kuantitatif yaitu data yang berupa angka-angka yakni data harga saham penutup semua emiten pada sektor pertambangan di Bursa Efek Indonesia selama periode 2016 dengan menggunakan closing price (harga penutupan) mingguan dan data total aset yang dimiliki emiten sektor pertambangan pada periode 2016. Sumber data yang digunakan dalam penelitian ini adalah data sekunder yaitu data yang telah tersedia di Bursa Efek Indonesia dan www.yahoo.finance.com.

Menurut Sugiyono (2016:90), populasi adalah wilayah generalisasi yang terdiri atas obyek/subyek yang mempunyai kualitas dan karakteristik tertentu yang ditetapkan oleh peneliti untuk dipelajari dan kemudian ditarik kesimpulannya. Populasi dalam penelitian ini adalah semua perusahaan sektor pertambangan di Bursa Efek Indonesia yaitu sebanyak 42 perusahaan. Teknik penarikan sampel dalam penelitian ini adalah purposive sampling. Adapun kriteria-kriteria yang digunakan dalam menentukan sampel dalam penilitian ini adalah:

1. Perusahaan yang tidak melakukan stock split selama periode penelitian.

2. Perusahaan yang memiliki data keuangan yang lengkap selama periode penelitian.

3. 5 perusahaan dengan size tertinggi pada sektor pertambangan dengan menilai dari total asetnya.

Adapun sampel dalam penelitian ini adalah sebagai berikut: 
Tabel 2 Sampel Penelitian

\begin{tabular}{|c|c|c|c|c|}
\hline NO & $\begin{array}{c}\text { KODE } \\
\text { PERUSAHAAN }\end{array}$ & NAMA PERUSAHAAN & SUB SEKTOR & $\overline{\text { TOTAL ASET }}$ \\
\hline $\mathbf{1}$ & ADRO & Adaro Energy Tbk & Batu Bara & $\begin{array}{c}\$ \\
6.522 .257 .000\end{array}$ \\
\hline 2 & MEDC & $\begin{array}{c}\text { Medco Energy International } \\
\text { Tbk }\end{array}$ & $\begin{array}{l}\text { Minyak dan Gas } \\
\text { Bumi }\end{array}$ & $\begin{array}{c}\$ \\
3.597 .130 .603\end{array}$ \\
\hline 3 & BUMI & Bumi Resources Tbk & Batu Bara & $\begin{array}{c}\$ \\
3.102 .193 .700\end{array}$ \\
\hline 4 & ANTM & Aneka Tambang Tbk & Logam & $\begin{array}{c}\$ \\
2.237 .428 .046\end{array}$ \\
\hline 5 & PTBA & $\begin{array}{c}\text { Tambang Batubara Bukit } \\
\text { Asam Tbk }\end{array}$ & Batu Bara & $\begin{array}{c}\$ \\
1.428 .982 .615\end{array}$ \\
\hline
\end{tabular}

Sumber: Data diolah

\section{HASIL DAN PEMBAHASAN}

\section{Hasil Penelitian}

\section{Pergerakan Harga Saham Individual}

Gambar 2 berikut memperlihatkan 3 pola trend dari 5 harga saham yang diteliti. Trend pertama adalah fluktuasi harga saham yang cenderung meningkat selama tahun 2016, dialami oleh saham ADRO, PTBA dan ANTM. Trend kedua memperlihatkan harga saham yang cukup stabil sejak triwulan pertama hingga ketiga tetapi mengalami kenaikan pada triwulan empat, dimana trend ini terjadi pada harga saham BUMI. Trend ketiga memperlihatkan saham yang cukup stabil sepanjang tahun 2016, sebagaimana yang dialami oleh saham MEDC.



\section{Return dan Risiko Saham Individual}

Adapun return ekpektasi mingguan saham ADRO, MEDC, BUMI, ANTM dan PTBA disajikan pada gambar 3 (a) sampai dengan (e) dibawah ini: 
Junaedi
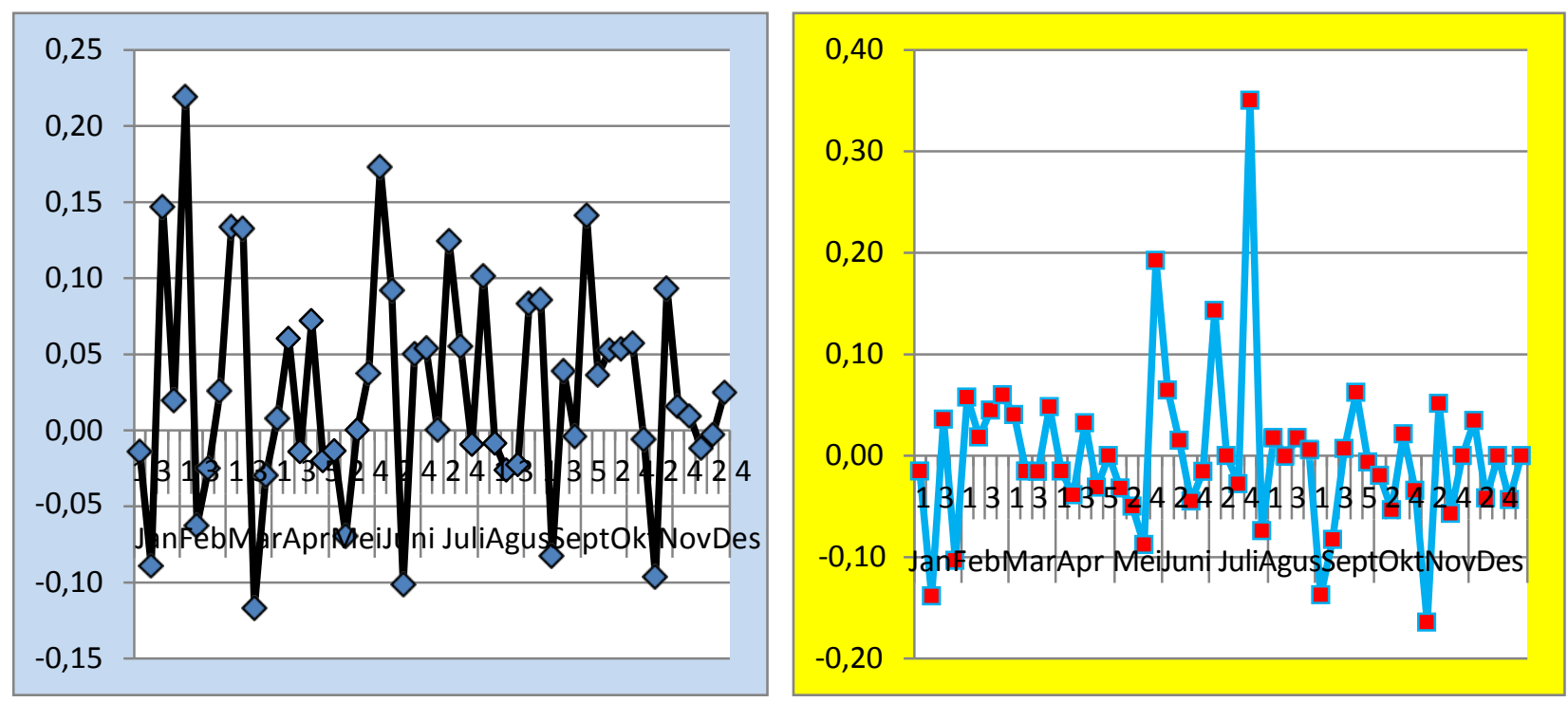

Gambar 3 (a) Return Saham ADRO dan (b) Return Saham MEDC

Terlihat pada gambar 3 (a) di atas, fluktuasi return saham ADRO berada pada level $10-15 \%$. Peningkatan return saham terbesar terjadi pada minggu pertama bulan februari yang mencapai $22 \%$. Hal ini disebabkan oleh adanya keputusan PT Adaro Energy untuk tidak lagi berfokus pada bisnis inti yaitu sektor batubara yang harganya selalu berfluktuasi. Perusahaan ini akan memaksimalkan bisnis lain dibidang logistik dan pembangkit listrik (power plant). Sehingga perusahaan ini nantinya akan mengambil bagian diberbagai bidang operasional. Selanjutnya, penurunan return saham terbesar terjadi pada minggu ketiga bulan maret hingga mencapai $-12 \%$. Hal ini terjadi akibat dari meningkatnya beban pokok guna merealisasikan kedua bidang bisnis tersebut yang diikuti dengan menurunnya harga jual batubara.(Sumber: www.sindonews.com)

Sebagaimana ditunjukkan pada gambar 3 (b) diatas, dapat dilihat bahwa return saham MEDC berada pada zona fluktuasi dibawah 5\%. Pada minggu ke empat bulan Mei, terjadi kenaikan return saham MEDC yang mencapai 19\%. Kenaikan ini disebabkan oleh adanya proses akuisisi kepemilikan hak partisipasi Japex Block A Ltd's sebesar 16,67\% di Blok A Production Sharing Contract (PSC), melalui anak usaha PT Medco E\&P Malaka. Selanjutnya, peningkatan return saham terbesar terjadi pada minggu ke empat bulan juli yaitu mencapai 35\%. Peningkatan return saham ini disebabkan oleh adanya proses akuisisi saham PT Amman Mineral Internasional (AMI) yang mengendalikan 82,2\% dari PT Newmont Nusa Tenggara (NNT) dengan nilai US\$2,6 miliar atau sekitar Rp34,32 triliun. Sedangkan titik terendah return saham MEDC terjadi pada minggu pertama bulan November yaitu mencapai $-16 \%$. Hal ini terjadi akibat dari turunnya pendapatan bersih yang mencapai $15.8 \%$ dari tahun sebelumnya. Penurunan ini disebabkan harga jual rata-rata batu bara ang juga mengalami penurunan hingga $14 \%$ dan turunnya volume penjualan mencapai 40 metrik ton $(\mathrm{t})$. (Sumber: www.sindonews.com) 

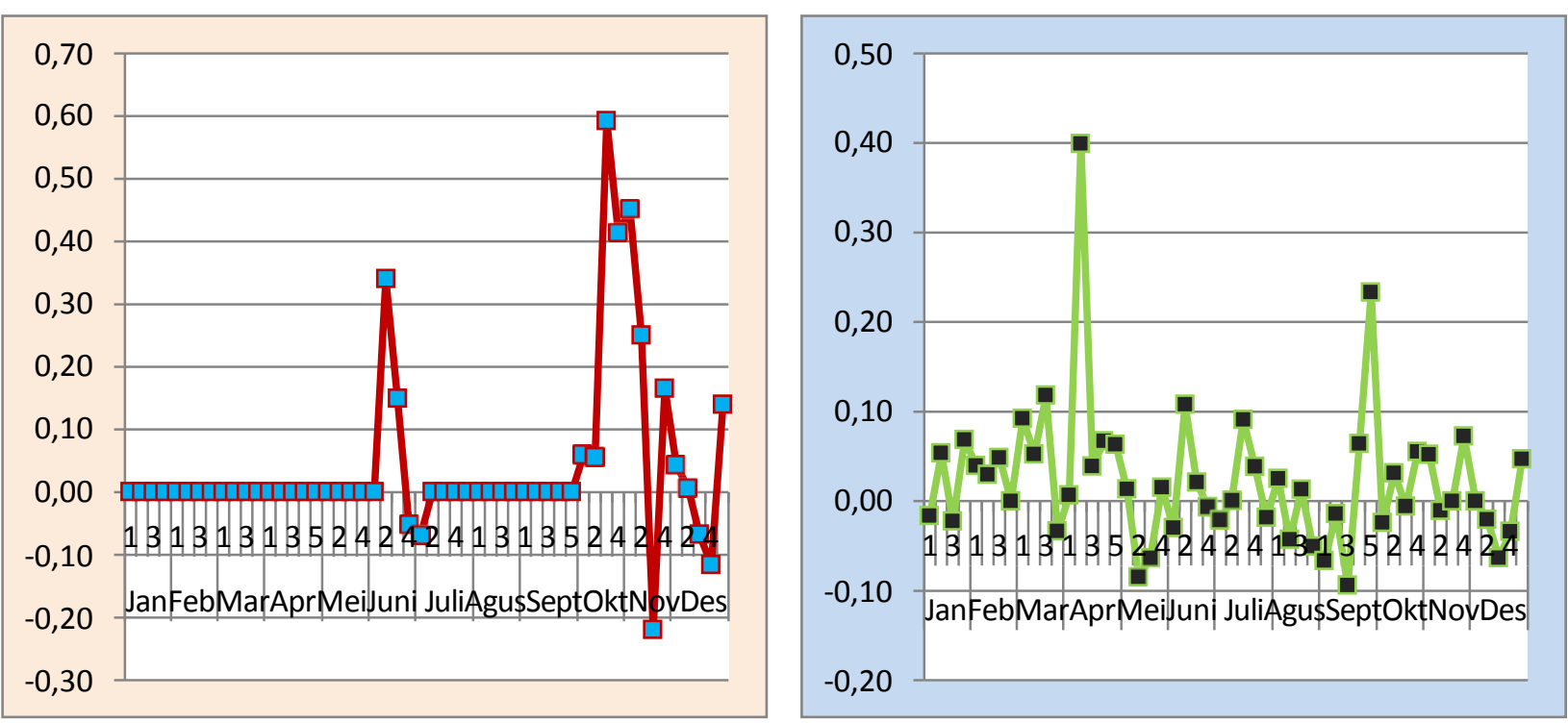

Gambar 3 (c) Return Saham BUMI dan (d) Return Saham ANTM

Pada gambar 3 (c) diatas, menunjukkan bahwa zona fluktuasi return saham BUMI berada pada tingkat $0-5 \%$. Peningkatan return saham terbesar terjadi pada minggu ke tiga bulan oktober yang mencapai 59\%. Hal ini terjadi akibat dari bergejolaknya harga saham ini, sehingga memicu para pelaku pasar untuk berinvestasi. Akibat dari bergejolaknya harga saham ini, maka BEI melakukan suspensi saham (penghentian aktivitas sementara perdagangan) pada saham BUMI karena dianggap kenaikannya tidak wajar. Hal inilah yang kemudian berdampak pada penurunan return saham pada minggu berikutnya. Sedangkan titik terendah return saham BUMI terjadi pada minggu ketiga bulan November yang mencapai $-22 \%$. Turunnya return ini terjadi akibat dari belum terselesainya pembayaran hutang, sehingga perusahaan ini melakukan perjanjian perdamaian dengan krediturnya melalui konversi hutang menjadi saham BUMI dengan harga per saham Rp 926,16. (Sumber: www.metrotvnews.com)

Gambar 3 (d) diatas menyajikan informasi return saham ANTM yang bergerak pada zona fluktuasi dibawah 10\%. Adapun return saham tertinggi terjadi pada minggu kedua bulan April yang mencapai 40\%. Hal ini disebabkan oleh adanya penandatanganan Project Development Agreement antara PT Aneka Tambang dengan Cronimet Holding $\mathrm{GmbH}$ dan Ferrostaal Industrial Projects GmbH dari Jerman untuk mengembangkan fasilitas produksi feronikel di Sulawesi Tenggara. Proyek kerjasama ini diyakini dapat meningkatkan sumber daya nikel ANTM. Selanjutnya, return saham terendah terjadi pada minggu ketiga September yang mencapai -9\%. Penurunan ini terjadi akibat dari melemahnya harga jual dan beli kembali (buyback) emas ANTM hingga Rp 4.000/gram. Sejalan dengan melemahnya harga emas dunia. Namun, dua minggu setelahnya return saham ANTM kembali mengalami peningkatan hingga 23\%. Naiknya return ini terjadi akibat dari membaiknya harga jual dan beli kembali emas ANTM yang naik Rp 2.000/gram. Didukung dengan stabilnya perdagangan emas di Asia yang meningkat $0.28 \%$. (Sumber: www.sindonews.com) 


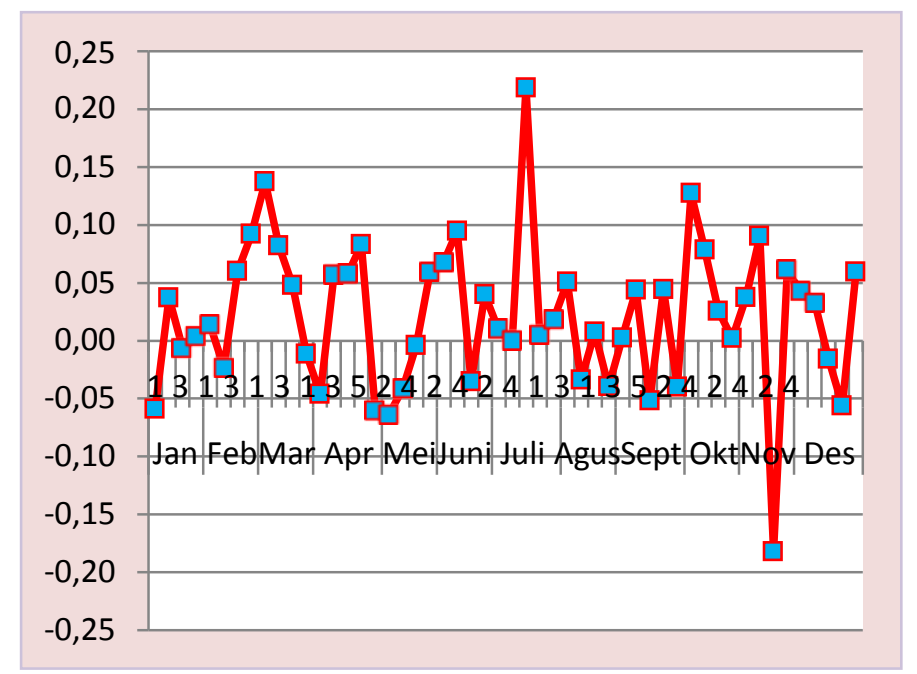

Gambar 3 (e) Return Saham PTBA

Return saham PTBA yang disajikan pada gambar 3 (e) diatas menunjukkan bahwa zona fluktuasi return saham PTBA berada pada titik 5-10\%. Adapun return tertinggi terjadi pada minggu ketiga bulan Juli yang mencapai $22 \%$. Hal ini disebabkan oleh membaiknya harga batubara mencapai $25.16 \%$ atau US $\$ 60.55 /$ metrik ton dan meningkatnya harga gas alam, sehingga pasar lebih memilih batubara. Sedangkan, return saham terendah terjadi pada minggu ketiga November yaitu sebesar $-18 \%$. Penurunan ini terjadi akibat dari turunnya permintaan komoditas batubara pada beberapa Negara tujuan ekspor seperti Tiongkok dan India. Akibatnya, harga saham pun ikut menurun mencapai 18\% dari harga saham pada minggu sebelumnya. (Sumber: www.sindonews.com)

Adapun return dan risiko saham individual dan return dan risiko portofolio disajikan pada gambar 4 (a) dan 4 (b) dibawah ini:
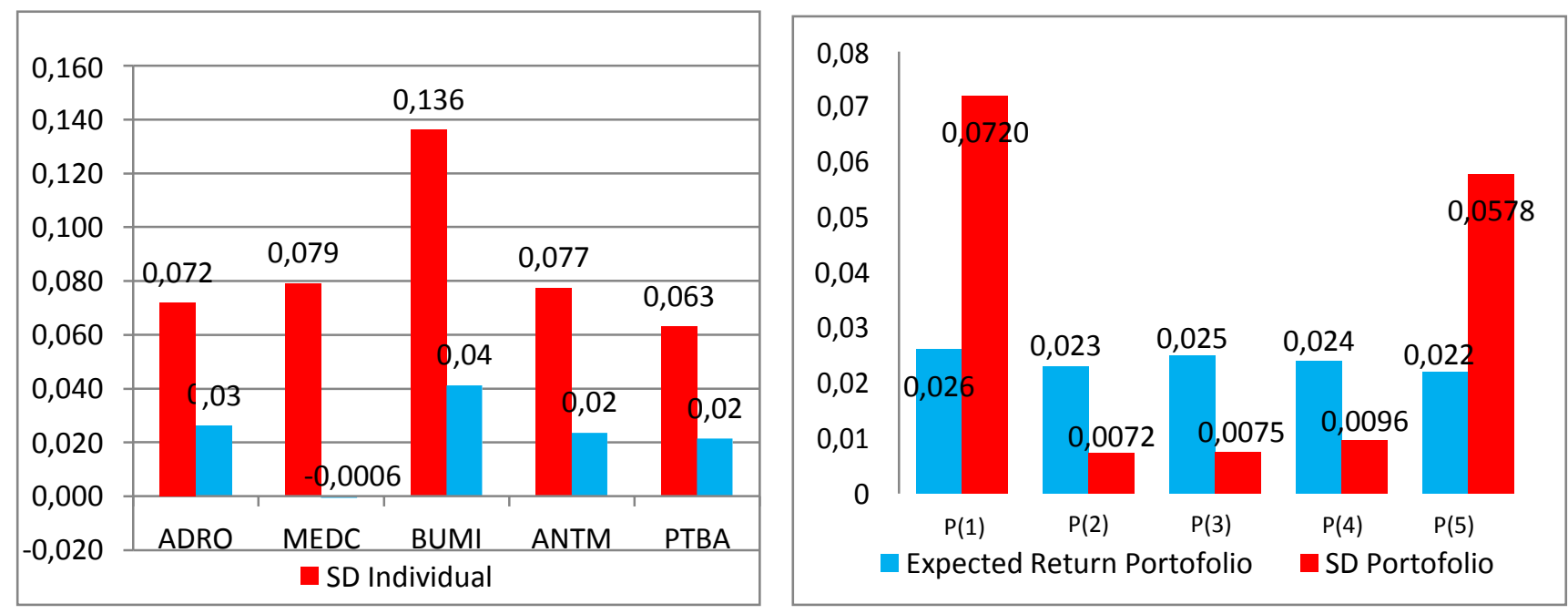

Gambar 4 (a) Return dan Risiko Individual dan 4 (b) Return dan Risiko Portofolio

Sebagaimana yang ditunjukkan pada gambar 4 (a) diatas, return ekpektasi pada saham ADRO sebesar 3\% dengan tingkat risiko sebesar $7.2 \%$, risiko ini lebih tinggi $0.007 \%$ dibandingkan saham MEDC yang mencapai $7.9 \%$ dengan return ekpektasi terendah dari kelima saham yang diteliti yakni hanya sebesar $-0.06 \%$. Pada saham BUMI, return ekspektasi mencapai $4 \%$ dan merupakan return ekspektasi tertinggi dengan tingkat risiko yang juga cukup tinggi yaitu $13.6 \%$ atau $5.7 \%$ lebih tinggi 
dibandingkan risiko pada saham MEDC. Return ekspektasi pada saham ANTM dan PTBA sebesar $2 \%$. Risiko pada saham ANTM sebesar $7.7 \%$ atau lebih tinggi $1.4 \%$ dibanding risiko pada saham PTBA yang hanya sebesar $6.3 \%$.

Pada gambar 4 (b) saham yang membentuk portofolio dimasukkan secara berurutan berdasarkan size tertinggi dengan menilai dari total asetnya masing-masing, yaitu; ADRO,MEDC, BUMI, ANTM dan PTBA. Portofolio 1 saham yaitu ADRO merupakan portofolio dengan risiko tertinggi yaitu sebesar 0,0720 atau 7.2\%. Sejalan dengan tingginya risiko, return ekspektasi pada portofolio ini juga cukup tinggi yaitu 0.026 atau 2.6\%. Selanjutnya, pada portofolio yang terdiri dari 2 saham yaitu ADRO dan MEDC, memberikan risiko portofolio 6.48\% lebih rendah dibanding risiko portofolio 1 saham dengan tingkat return ekspektasi sebesar 0.023 atau 2.3\%. Penurunan risiko yang signifikan ini terjadi akibat dari fluktuasi return saham yang tidak searah antara ADRO dan MEDC.

Portofolio 3 saham dibentuk dari saham ADRO, MEDC dan BUMI dengan tingkat risiko portofolio sebesar 0.0075 , meningkat 0.0003 dibanding portofolio yang terdiri dari 2 saham. Namun, return ekspektasi pada portofolio ini juga mengalami peningkatan menjadi $2.5 \%$. Hal ini terjadi disebabkan oleh masuknya saham BUMI yang memiliki fluktuasi return saham yang cukup stabil. Peningkatan risiko portofolio kembali terjadi pada portofolio yang dibentuk dari 4 saham yaitu ADRO, MEDC, BUMI dan ANTM hingga mencapai 0.0096 dengan tingkat return ekspektasi yang juga mengalami penurunan menjadi $2.4 \%$. Hal ini terjadi akibat dimasukkannya saham ANTM yang memiliki fluktuasi return saham yang hampir sama atau searah dengan saham ADRO. Pada portofolio yang terdiri dari 5 saham yaitu ADRO, MEDC, BUMI, ANTM dan PTBA, risiko portofolio mengalami peningkatan yang cukup signifikan hingga mencapai 0.578 atau 5.78\% lebih rendah $1.42 \%$ dibanding dengan risiko portofolio 1 saham. Peningkatan risiko ini terjadi akibat dari penambahan saham PTBA yang memiliki return saham yang sangat berfluktuasi dan hampir sama atau searah dengan saham ADRO dan ANTM. Adapun return ekspektasi pada portofolio yang dibentuk dari 5 saham ini sebesar 0.022 atau $2.2 \%$ dan merupakan portofolio dengan return terendah dari semua portofolio yang dibentuk. Portofolio 5 saham dalam penelitian ini merupakan portofolio efisien, sedangkan portofolio 3 saham merupakan portofolio optimal.

\section{Pembahasan}

Hasil penelitian ini, menunjukkan bahwa return saham ADRO, BUMI, ANTM dan PTBA memiliki hubungan dengan risiko saham individualnya masing-masing. Hal ini ditunjukkan dengan adanya pergerakan yang searah, ketika risiko saham individual tinggi maka return sahamnya pun akan tinggi, begitupun sebaliknya. Namun, kondisi yang berbeda tergambar pada saham MEDC, dimana return ekspektasi pada saham ini hanya sebesar $-0.06 \%$ berbanding terbalik dengan risiko saham individual yang cukup tinggi hingga mencapai 7.9\%. Berdasarkan hasil penelitian ini, penulis menyimpulkan bahwa ketika harga saham cenderung mengalami penurunan dan berada pada return saham dibawah 0 atau bahkan minus, kondisi tersebut dapat meningkatkan risiko saham individual jika terjadi berulangkali dalam 1 periode. Kondisi inilah yang terjadi pada saham MEDC.

Sudana (2011:51), kemudian menambahkan teori diversifikasi yang menyatakan bahwa semakin banyak jumlah aset yang membentuk portofolio, risiko portofolio akan semakin berkurang, karena adanya bagian dari risiko total yang bisa dikurangi yang disebut risiko tidak sistematik. Sebagaimana yang terlihat pada gambar 4 (b) diatas, menunjukkan bahwa pada portofolio 1 saham yaitu ADRO risiko portofolionya mencapai 7.2\% dengan kovarian sebesar 2.77. Ketika saham MEDC ditambahkan kovariannya menjadi 0.31 dengan tingkat risiko portofolio sebesar $0.72 \%$. Penurunan yang cukup signifikan ini terjadi diakibatkan oleh hubungan kovarian yang tidak searah. Selanjutnya, ketika saham BUMI dimasukkan risiko portofolionya menjadi $0.75 \%$ dengan tingkat kovarian sebesar 0.30 . Peningkatan risiko portofolio mulai terjadi ketika saham ANTM dan PTBA ditambahkan masingmasing sebesar $0.96 \%$ dan $5.78 \%$ dengan tingkat kovarian masing-masing sebesar 0.40 dan 2.63. 
Elton dan Gruber (1977), dalam penelitiannya menemukan hasil bahwa risiko total portofolio sebesar 46.811 dan ketika saham terus ditambahkan hingga 6 saham, risiko total telah teriliminasi sebesar 70.76\%. Penelitian Statman (1987), menyimpulkan bahwa ketika 6 saham telah ditambahkan, risiko portofolio telah menurun sebesar $45.88 \%$ dari risiko total portofolio sebesar 49.236. Selanjutnya, Ahuja (2011), dalam penelitiannya menyimpulkan hasil bahwa risiko total portofolio adalah sebesar $4.1804 \%$ dan ketika 5 saham ditambahkan risiko portofolio telah tereliminasi sebesar $50.90 \%$. Hasil penelitian yang dilakukan Suqaier dan Ziyud (2011), menyimpulkan bahwa risiko total portofolio adalah sebesar 11.19 dan pada saat 5 saham ditambahkan telah mengeliminasi sebesar $43.69 \%$ dari total risiko portofolio. Beberapa penelitian diatas menunjukkan bahwa terdapat pengurangan risiko total portofolio, seiring dengan ditambahkannya saham ke dalam portofolio. Hal ini sejalan dengan hukum "large number", ang men atakan bahwa jika menambahkan secara terus menerus berbagai jenis saham ke dalam portofolio, maka manfaat pengurangan risiko yang diperoleh akan semakin besar, sampai mencapai titik tertentu apabila portofolio ditambah dengan satu saham atau lebih, tidak akan terjadi penurunan risiko yang berarti. Sedangkan dalam penelitian ini, risiko portofolio 5 saham justru mengalami peningkatan seiring dengan ditambahkannya saham ANTM dan PTBA yang masing-masing sebesar 28\% dan $670 \%$ dari risiko portofolio 3 saham.

Meningkatnya risiko portofolio ini disebabkan oleh hubungan kovarian yang searah antara saham ADRO, ANTM dan PTBA yang searah. Saquier dan Ziyud (2011), membenarkan hal ini dan mengatakan bahwa peningkatan risiko portofolio ini terjadi karena sekuritas berisiko tinggi dengan korelasi yang tinggi pula ketika menambahkan sekuritas lain. Tingginya hubungan korelasi antar saham ini disebabkan oleh kelima saham yang digunakan merupakan saham dari satu sektor yakni pertambangan. Menurut Sudana dan Janiarti (2000) dalam Tyas dan Sudana (2013), bahwa pembentukan suatu portfolio melalui diversifikasi saham beragam industri menghasilkan risiko yang lebih kecil daripada penyusunan portofolio melalui diversifikasi saham satu industri. Markowitz (1952), juga menyarankan hal yang sama yaitu menjauhi investasi dengan kovarian yang tinggi. Lebih lanjut, Markowitz (1952), menyatakan bahwa kecukupan sebuah diversifikasi tidak hanya tergantung pada jumlah sekuritas yang dipegangnya, melainkan haruslah berasal dari perusahaan industri yang berbeda dengan kovarian yang rendah. Sundjaja dan Berlian (2002: 62), menambahkan bahwa mengombinasikan aktiva yang tidak berkorelasi dapat mengurangi risiko, walaupun tidak seefektif mengombinasikan aktiva yang berkorelasi negatif. Oleh karena itu, penulis menganggap perlu menghindari investasi pada kovarian yang tinggi dengan berinvestasi pada industri yang berbeda, sehingga kerugian pada saham satu akan tertutupi oleh peningkatan saham lainnya.

Berdasarkan hasil penelitian yang dilakukan, dari 5 portofolio yang dibentuk. Portofolio dari 3 saham yaitu ADRO, MEDC dan BUMI merupakan portofolio optimal dengan tingkat return ekspektasi sebesar $2.5 \%$ dan risiko portofolio sebesar $0.75 \%$. Adapun persentase dana yang diinvestasikan yaitu sebesar $81.3 \%$ pada saham ADRO, sebesar $10.7 \%$ pada saham MEDC dan sebesar $8 \%$ pada saham BUMI. Sebagaimana yang dikatakan oleh Markowitz (1952), jika seorang investor menginginkan return antisipasi yang maksimal dari portofolionya maka dia seharusnya menempatkan semua dananya pada sekuritas dengan return antisipasi yang maksimal.

Menariknya, dua perusahaan yang dijadikan portofolio optimal dalam penelitian ini juga melakukan operasi pertambangan di Provinsi Sulawesi Tengah, sebut saja anak perusahaan Medco Energy International Tbk yakni Medco E \& P Tomori Sulawesi yang beroperasi di wilayah Senoro Toili, Kabupaten Banggai dan anak perusahaan Bumi Resources Tbk yakni Bumi Resources Minerals Tbk yang beroperasi di wilayah pertambangan emas Poboya, Palu. 


\section{KESIMPULAN DAN SARAN}

\section{Kesimpulan}

Adapun kesimpulan dari penelitian ini adalah sebagai berikut:

Diversifikasi mempengaruhi risiko portofolio ketika portofolio hanya terbentuk sampai dengan 3 saham yaitu ADRO, MEDC dan BUMI, sehingga hipotesis awal diterima. Namun, ketika saham ANTM dan PTBA ditambahkan ke dalam portofolio, risiko mengalami peningkatan sehingga hipotesis awal ditolak untuk portofolio 5 saham. Proporsi dana pada portofolio 3 saham, yaitu; 81.3\% (ADRO), $10.7 \%$ (MEDC) dan $8 \%$ (BUMI) yang akan menghasilkan risiko portofolio sebesar $0.75 \%$ dan return ekspektasi sebesar $2.5 \%$.

\section{Saran}

Berdasarkan hasil penelitian, yang disarankan penulis adalah sebagai berikut:

1. Peneliti selanjutnya diharapkan menggunakan teknik random sampling dalam penarikan sampel, sehingga semua populasi memiliki peluang yang sama untuk dijadikan sampel penelitian.

2. Menggunakan sampel 10-15 saham untuk melihat tingkat penurunan risiko portofolio secara signifikan dan menggunakan sampel dari industri yang berbeda untuk menjauhi investasi yang memiliki kovarian yang tinggi.

3. Menggunakan periode penelitian yang lebih lama yaitu 2-5 tahun agar lebih menggambarkan pergerakan harga saham.

\section{REFERENSI}

Ahuja, Aakash, 2011. Portfolio Diversification In the Karachi Stock Exchange. PJETS, Volume 1, No. 1, 2011, $p$ 37-44. ISSN: 2222-9930

Awat, Napa J dan Muljadi, 1996. Keputusan-keputusan Keuangan Perusahaan. Jogjakarta: Liberty.

Bodie, et al, 2014. Manajemen Portofolio dan Investasi. Jakarta: Salemba Empat.

Elton, Edwin J and Guber, Martin J, 1977. Risk Reduction and Portfolio Size: An Analytical Solution.

The Journal of Business, Volume 50, Issue 4 (Oct., 1977), 415-437.

Fahmi, Irham, 2015. Manajemen Investasi, Edisi 2. Jakarta: Salemba Empat.

Fama, Eugene F, 1970. Efficient Capital Markets: A Review of Theory and Empirical Work. The Journal of Finance, Vol. 25 No. 2, Papers and Proceedings of the Twenty-Eight Annual Meeting of the American Finance Association New York, N.Y. December, 28-30, 1969 (May, 1970), pp. 383-417.

Harjito, Agus dan Martono, 2014. Manajemen Keuangan Edisi ke 2. Yogyakarta: Ekonesia.

Jogiyanto, H, 2014. Teori dan Praktik Portofolio dengan Excel. Jakarta: Salemba Empat.

Jones, Charles P, 2004. Investment Analysis and Management, Ninth Edition. New York: John Wiley \& Sons.

Markowitz, Harry M, 1952. Portfolio Selection. The Journal of Finance, Vol. 7, No.1. (Mar.,1952), pp. 77-91.

Muslich, Mohamad, 1997. Manajemen Keuangan Modern. Jakarta: Bumi Aksara.

Samsul, Muhammad, 2006. Pasar Modal dan Manajemen Portofolio. Jakarta: Erlangga.

Sudana, I Made, 2011. Manajemen Keuangan Perusahaan Teori dan Praktik. Jakarta: Erlangga.

Sundjaja, Ridwan J dan Berlian, Inge, 2002. Manajemen Keuangan Dua. Jakarta: Ikrar Mandiri Abadi.

Sugiyono, 2016. Metode Penelitian Administrasi. Bandung: Alfabeta.

Sugiyono, 2014. Metode Penelitian Kombinasi. Bandung: Alfabeta. 
Suqaier, Faten S dan Ziyud, Hussein A, 2011. The Effect of Diversification on Achieving Optimal Portfolio. European Journal of Economics, Finance and Administrative Sciences. ISSN: 14502275 Issue 32, 2011.

Statman, Meir, 1987. How Many Stock Make a Difersified Portfolio?. Journal of Financial and Quantitative Analysis, Vol. 22, No. 3, September 1987, 353-363.

Titman, et al, 2011. Financial Management Principles and Aplication. New York: Pearson Education. Tyas Auruma, S dan Sudana, I Made, 2013. Diversifikasi Investasi Saham: Perbandingan Risiko Total Portofolio Melalui Diversifikasi Domestik dan Internasional. JurnalManajemen Teori dan Terapan Tahun 6, No.1, April 2013.

Van Horne, James C, 2002. Financial Management and Policy. New Jersey: Phipe Prentice Hall. 